\title{
近代京都の東山地域における別邸群の初期形成事情 \\ THE EARLY STAGE OF MAKING A GROUP OF GUEST-HOUSES AROUND THE HIGASHIYAMA-AREA IN THE MODERN PERIOD, KYOTO
}

\author{
矢ヶ崎 善太郎* \\ Zentaro YAGASAKI
}

\begin{abstract}
After the construction of the Lake-Biwa Canal, some guest-houses (villas) were built around the Higasiyama-area, in Kyoto. Yamagata-Aritomo started to build a guest-house, named the 3rd MURIN-AN near the Nanzenji-temple. This building work was completed by the united efforts of some potentates in politics and industrial world. Making process of these guest-houses had mutural relations with the preservation of scenic beauty around the Higashiyamaarea. Building work of the 3rd MURIN-AN by Yamagata accelerated the making this group of guest-houses.
\end{abstract}

Keywords: the Modern Period, Kyoto, guest-house (villa), SUKI-KUKAN, MURIN-AN, Yamagata-Aritomo 近代、京都、別邸、数寄空間、無隣庵、山縣有朋

\section{研究の目的}

明治の中期から昭和のはじめにかけて、京都の東山山麓、特に南 禅寺近傍では、政治家や実業家など東西の貴顕たちによって多くの 「別邸」あるいは「別荘」「山荘」などと呼ばれる邸宅施設が造営 され、そこでは建築と庭園とによって、いわゆる「数奇的な空間」 が営まれていた。その庭園の多くに、琵琶湖疏水の水か導入されて いることはよく知られている゙”。現存する遺構から判断すると、こ の「数寄的な空間」は、施主の豊かな経済力を背景にして営まれた もので、茶の湯によるもてなしや茶会が可能な施設を構えるなど、 様々な趣味的生活を可能にするものであった。

遺構の庭園の多くが琵琶湖疏水からの水系で結ばれており、それ らの庭園が流れる水のデザインを特徴としている2)ことから、琵琶 湖疏水の開通以後、疏水の水を邸内に導入することが可能であるこ とを前提条件として当地域に多くの別邸が建設されたことは容易に 想像できる。しかしそれは、施主となる貴顕たちが恣意的に琵琶湖 疏水のまわりに邸を営み、偶然に別邸群が形成されたのでなく、当 地での別邸の造営を促す、当地域ならではのより積極的な誘因がほ かにいくつかあって、琵琶湖疏水の水が利用できる環境のもとで集 中的に別邸群か汧成されたものであった。すなわちこの別邸群は近 代の京都、特に東山という地域固有の性格を背景にして成立したも
のであったと考えられる。

本稿は、当地で最初期に別邸を営んだ山䝮有朋の別邸造営の経緯 から、別邸地が形成される初期の状況を探り、このような別邸群の 形成が先ず何によって推進されたのかを明らかにしようとするもの である。これはこれら別邸群の多くに共通して営まれた、建築と庭 園とによる「数奇的な空間」に、近代の茶の湯の場としての性格を 見いだし、それを数寄空間の展開の歴史の中に特徵的に位置付ける ための準備作業としても位置付けられるものである。

なお、ここで用いる「東山地域」あるいは「南禅寺近傍」とは、 地域を厳密に限定しているものではなく、京都の東山山麓で琵琶湖 疏水が通過する、現在の左京区粟田口・南禅寺・岡崎 - 聖護院・鹿 ヶ谷・浄土寺付近を漠然と示しいている(〈図ー1〉)。また、別 邸や別荘、山荘の呼称も特に区別するものでい。利用状況から本 邸・別邸いずれとも判断し難い施設も少なくない。厳密な性格付け の必要性に関しては今後検討することとして、ここでは本稿で用い た史料あるいは参考文献の用例にならって、主として「別邸」の語 を用いることとする。

\section{1 東山地域の風致保存と別邸地化}

本節では、明治23年 (1890) 琵琶湖疏水開通以後の東山地域の変

\footnotetext{
* 京都国際建築技術専門学校建築科 教員・工修
} Lecturer., Dept. of Architecture, Kyoto Architectural School of Engineering, 


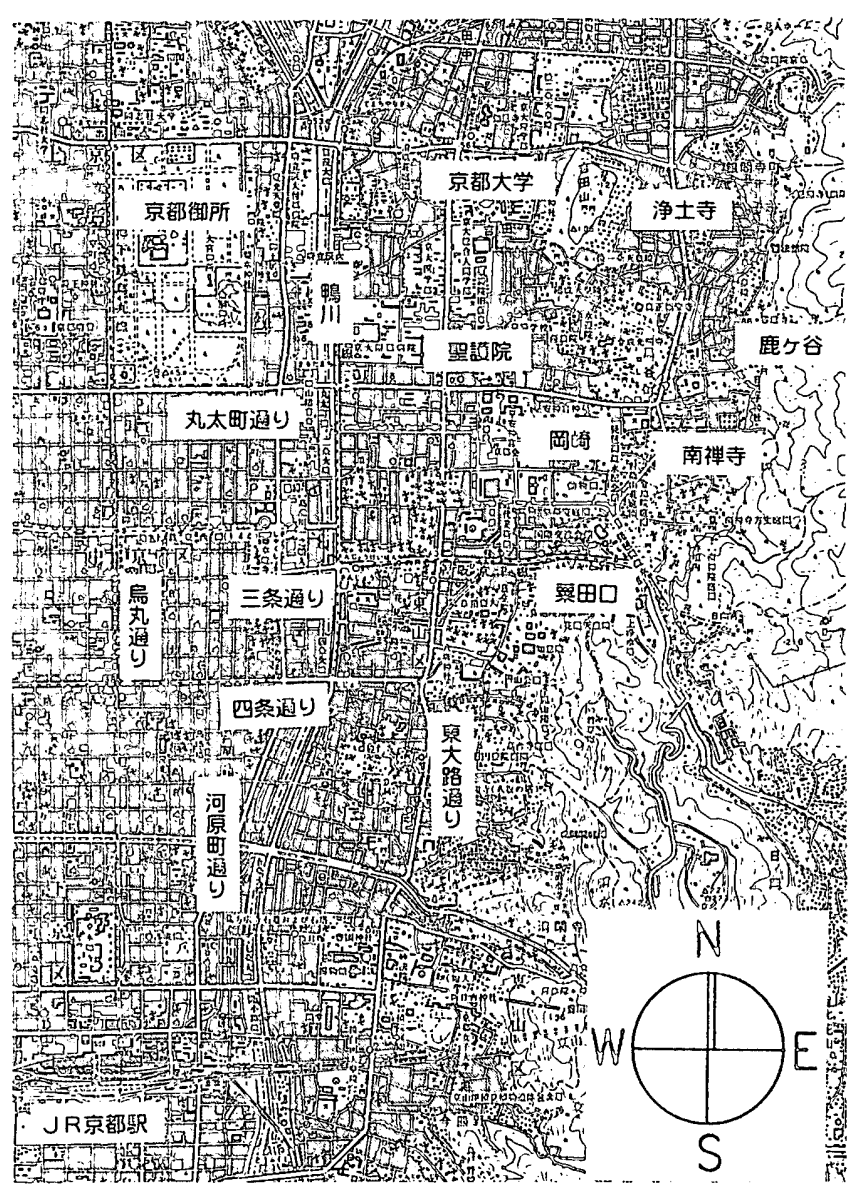

〈図-1)「現在の東山地域」

国土地理院1:25,000地形図「京都東南部」をもとに作成。 点線は琵琶湖疏水を示す。

貌を、周知の莗赛を踏まえ、新たな知見を加えながら概観し、本稿 を展開する背景を述べる゙!。

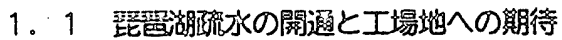

近代京都の発展は、琵琶湖疏水の開通に拠るところがきわめて大 きかったことはいうまでもない。特に瞣富な水流か通過する、東山 山簏の南禅寺から岡崎付近にかけての地域にとっては、その地域的 性格を決定づけるほどの多大な影響がもたらされた。

明治16年（1883）の琵琶湖疏水『起工趣意㫪』に示された疏水專 業の目的のうち、水車動力による製造工業の近代化は、機業をはじ めとする京都の伝統産業界にとって、きわめて期待の大きなところ であったと推察できる゙。

琵琶湖疏水の造営がすでに始まっていた明治22年（1889）3月に 立案された『疏水及び編入地域（二十一年）を中心とする市街画定 案』 5)では、その前文で、蕙山の風景を「京地二テ最愛スへキ」も のとし、南禅寺門前から永観堂。銀閣寺門前に至るまでの地域を 「恵山二於テ最良ノ風景习有スルノ勝地」などと、曺山の風光を謳 う一方で、「客年六月当府令第七拾号习以テ愛宕郡南禅寺祄外八ヶ 村习新区部入御編入相成、右八琵琶湖疏水成功ノ後八渐力熱閏ノ市 区二変移スへキ時運二向七、加ル二高等中学校 $习$ 始墭大ナル二三 ノ製造所 モモ建築中二テ、其盛兆予メト知スヘキノ現況二有之」 と、すでに琵琶湖疏水の完成を期待した製造工場が建設中であるこ とを伝えていた。
明治20年 (1887) 、京都織物株式会社が設立する ${ }^{6)}$ 。撚系。染 色・織物の一貫作業による近代的システムを備えた織物会社で、京 都府の産業復興事業の一環として明治 7年 (1874) に設立された 「織工場」（同10年より「織殿」）の事業を引き継ぐものであっ た。同社は設立と同時に、社屋および工場建設用地として愛宕郡吉 田村吉田下阿達の官有地の払い下げを受け、さらに将来の撚系工場 建設にそなえて、同年12月 2 日、南禅寺村下河原の旧南禅寺塔頭少 林院の地 5,130坪を購入する。この地は明治4 年 (1871) に上地 後、民間に払い下げられた後も特に開発されずにあっだ)。同地の 西側には白川が流れており、さらに東側に琵琶湖疏水が開通するこ とで水車動力が容易に得られる地理的条件をもって工埸建設の適地 と見込まれていたに違いない。

先の『疏水及ひ編入地域（二十一年）を中心とする市街画定案』 では、当地域内において、藤井紡纉会社の存在も示し、今後当地域

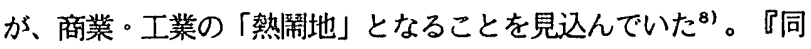
画定案』で、「建設中」と伝えられた「盛大ナル二三ノ製造所」と は、これらの紡緽、織物工場などを示していたものと考えられる。 明治維新以来の復興を目指す京都にとって、琵琶湖疏水開通にとも なう工場建設がもたらす地域の繁栄に、大きな期待か寄せられてい たことが賽える。

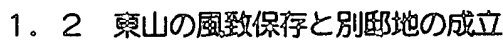

明治18年（1885）に着工した琵琶湖疏水第一期工事が同23年 (18 90）に竣工するまでの間に、水車による工業動力を水力発電に変更 したことはよく知られている。同22年（1889）に水力発電所の建設 が付帯工事として決定される。同24年（1891）には踣上発電所が建 設され、翌25年（1892）には電気事業が開始された ${ }^{9 !}$ 。先に見たよ うにすでにいくつかの工場が東山疏水付近に建設されてはいたもの の、水車による疏水路付近への工業動力の供給に代わって、京都市 内広域へ電力の供給が可能になったことで、琵琶湖疏水の水路付近 における工場建設をさらに促す大きな要因が失われたことになっ た。以後この水車動力から水力発電への変更を契機として、当地域 の新たな性格付けにつながるともとれる動きが散見される。

明治33年 (1900)、内兾甚三郎初代京都市長は、新しい都市構想 を提案した。それは「五十万以上百万ノ人口作ル京都トナス」も ので、次の内容をともなっていた ${ }^{101}$ 。

[「曺方八風致保存ノ必要アリ」「北方八西陣アッテ尚現況习 繼続」「教育機䦥ノ設備ヨナスノ地八高燥二シテ且ツ清橴ノ場 所习要スルラ以テ（中略）北西二筧メタシ」「西方八現在 田畑二テ別二風致上ノ閶係ナキニヨリ煙突林立スルモ何等差支 ヨ見ズ（中略）会社商館ノ如キ大建造物习収容スル」「宇 治川ノ雪動力习利用シテ伏見・媣草八勿諭、西八花总迄モ工業

ノ地トナセバ、前途京都ノ発展八甚夕多望ナルモノ」]

京都の地理的条件も考慮した地域別の開発構想が提示されたこと は注目されよう。商工菜の振興による都市的発展だけでなく、同時 に「風致保存ノ必要」も説き、それは「京都トシテ決シテ放裹入ベ カラザル事業ナリ」と続けていた"11。ここで風致保存の対象とし て最初に取り上げられた「菓方」とは、曺山の山容を背景にもつ、 明治21年（1888）6月に京都市に編入された東山山䌒地域で、本論 が主として対象にしている南禅寺近傍の地域を含むものであったこ とはまちがいない。 
この内貴京都市長の都市構想は、京都の人口増加を促すことを目 的に提案されており、その基本的性格は明治維新の東京奠都以来の 京都振興策とかわらないものである。「東方」の風致保存の方針は 単に歴史的環境の保存という一面的なものではなく、それによる派 生的な効果として、東山山麓地域が固有の発展をするであろう可能 性を見いだしていたともいえる。

実は、琵琶湖疏水第一期工事が完成した明治23年 (1890) 以後、 前述の内貫京都市長によって風致保存を含めた新たな都市構想が提 示された明治33年を前後して、風致の保存を前提として東山地域の 新たな性格を方針付けるような具体的な動きが確認できる。

次は、明治39年（1906）10月24日付「日出新聞」記事である。

[鐘淵紡績会社にては先に当市川端丸太町上る東入京都大学付 属病院西手の空地に絹糸紡績工場設置の儀を当府知事に出願せ しに当所は将来別荘地として発達すべき見込あり然るに日々多 量の石灰を消費する工業会社を設立するは風致を害するのみな らず接近せる病院に対しても少なからさる影響を及ぼすべしと の理由にて認可せられさりし]

京都府は明治 4 年 (1871) 鴨川の東岸、吉田村聖萑院領の元練兵 場跡に産業基立金を利用して牧畜場を設置していた ${ }^{12)}$ 。牧畜場閉 鎖後、鐘淵紡績会社は当地での絹糸紡績工場建設を京都府に申請し たが、京都府はそれを認可しなかった。記事はさらに、同社がその 後、田中村小字下竹屋 (現在の左京区高野) に5千800余坪の土地 を購入し工場建設の認可を得たことを報じていた。

この記事から、東山一帯を風致保存の対象とする京都府の方針が 確認できる。さらにその風致保存が「将来別荘地として発達すべき 見込」があるためであるとしていることが注目されよう。すなお ち、東山一帯が工埸地としてよりも、風致を保存すべき対象として 認識され、それと連動する現象として、付近に別邸地か形成されつ つあったことが簣えるのである。

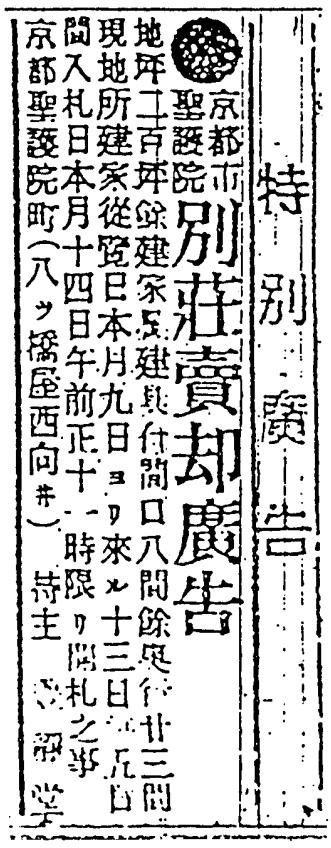

明治29年10月 9 日付「日出 新聞」の「別荘賣却廣告」
事実この時期、鴨川以東、南禅 寺を中心とする東山地域では、琵 琶湖疏水完成以後、別邸あるいは 別荘と呼ばれる施設が造営されて いた。

例えば後述するように、山縣有 朋が木屋町二条の別邸「第二次無 隣庵」の地を売却し、南禅寺近傍 で新たに「第三次無隣庵」の造営 準備を始めるのが、明治25年（18 92）頃であった。 4 年後の同29年 （1896）頃には庭園の最初の整備 が終わる。また同年、伊集院康常 が第三次無隣庵の近くに別邸を構 える ${ }^{13)}$ 。ともに実態がある程度 まで解明可能な別邸の初期の実例 であり、後に当地域での別邸群形 成に大きな影響を与えたことが予 想される。

明治29年（1896）10月 9日付

「日出新聞」に「別荘賣却」広告
が見いだせる。建家付き土地を「別荘」として売却するため、現地 の縦覽と入札の期間を広告するものである。所在地は鐘衔紡績会社 が絧系紡績工場の建設を予定した場所から程近い聖護院（原文では 「京都聖護院町 八ッ橋屋西向井」とある)であった。施設の実態 は詳らかでないが、この頃、当地で別邸に対する需要が期待できた ことを示しているとみなされよう。

また先述した通り、京都織物株式会社は、将来の撚糸工場建設地 として、明治20年（1887）12月 2 日、南禅寺村下河原にある旧南禅 寺所有地を購入していた。しかしその後当地で同社が撚系工場が建 設した事実はなく、結局同24年（1891）に吉田村の本社工場内で然 糸工場の操業を開始していた ${ }^{14)}$ 。旧南禅寺領のこの土地は明治27 年 (1894) 、吉田村の所有地の一部とともに大阪の中村弥吉なる人 物に売却される。これも琵琶湖疏水による水力発電の実現によっ て、南禅寺村での場建設を樻極的に促す要因が失われたことと、 付近が別邸地として性格付けられていたことによって、工場の建設 が困難であったことが原因であったであろうことは想像できよう。 以後この土地は所有者を替え、明治44年（1911）より隣地を所有す る角星合資会社によって、明らかに別邸地として開発されてい 〈15)。

管見で得た以上の 4 つの事例をして、琵琶湖疏水第一期工事の竣 工以後、東山地域の南禅寺近傍地域で別邸の建設が行われつつあつ たことを想像するに十分であろう。

以上から、東山地域の風致保存の方針か打ち出され、それが推進 される動きと連動して別邸地が形成されつつあったことがわかる。 そうすると風致保存のみならず東山地域での別邸の建設までもが行 政などによって人為的に導かれていた可能性も考えられよう。当地 域が工場地から風致保存の対象地域としてその性格をかえていくな かで、別邸の建設を促すことが、当地域の固有の発展につながり、 京都に、工場建設によるものとはちがう新たな繁栄をもたらすもの と期待されていたとも考えられるのである。

\section{2 山縣有朋の京都別邸「無隣庆」の造営事情}

本節では、東山地域の特に南禅寺近傍に営まれた別邸の最初期の 事例とみなされる山縣有朋の京都別邸「第三次無隣庵」について、 その造営に関わる山縣の動向を探り、当地域が別邸地として性格付 けられていく契機となった初期の具体的状況を明らかにする。別邸 造営に関わる山縣の動向を知る手がかりとしては地元の有力紙であ る「出新聞」の記事を主な史料とし、管見で得た他の史料でそれ を補う。

\section{1 第二次無隣庵の拡張計画と売却}

明治・大正期の元勲山緊有朋（1838～1922）は、公務多忙のなか にあっても常に趣味を蚎かにし、風流韻事の楽しみを忘れることは なかったという。わけて築庭術にかけては特筆すべきものがあっ $た^{26)}$ 。山縣が営んだいくつかの邸宅では、自らの指示で庭園を築 庭することが多かった。

山縣が生涯に営んだ邸のうち、無隣庵と呼ばれる邸は場所を替え て三次にわたって造営されている。このうち第一次無隣庵は幕末頃 郷里の長州吉田駅に営んだ邸で、第二次と第三次はともに京都の別 邸であったは7)。

京都で山縣は先ず鴨川西岸、木屋町二条に第二次無隣庵を営む。 


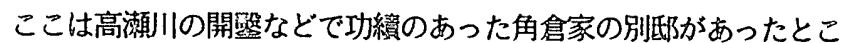
ろで、角倉本邸と不屋町通りを隔てた亩側に位置している （〈図-2〉参照）。ここは明治のはじめに上地されたものを、明 治24年（1891）7 月に山縣か瞳入したものであった ${ }^{18)}$ 。山縣がこ こでどのような普請を行ったのかは詳らかでないか、鴨川から分流 した豊富な水流が横切って高瀬川の起点となる当地の地形は、後に 山縣が理想とする庭園钼を形成するに至る重要な意㙅をもつもので あった。191

第二次無隣衤の地を手に入れて間むなく、山縣は敬地の拡張を計 画した。次は明治25年（1892）7月13日付「日出新聞」の記曹であ る。

[山临伯爵の別邸取拡げ - 京都木屋町二條下る山縣伯別邸 管理人下村一蝐氏より今度同邸取拡げの為め接近の鴨川沿岸地 所四十餘坪拝借の議を山縣伯の代理として府知事に出願したる に附き土不主任者は実地に就て視察せしが同择借出願地は地方 税経済に属する熥門及び熥守小屋の所在地なり且つ彼の鵤川横 断工尌を起すことにもならば特に必要なる所なれば此際同地所 貸下は断乎として拒絶せんことに内決せし由]

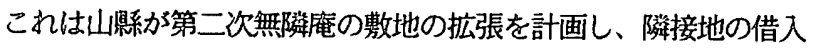
を京都附に申し出たが、京都府はその申し出を許可しなかったこと を伝えている。

この新聞報道からわずか 4 か月程後の明治25年 (1892) 11月、山 縣はこの不屋町二条の第二次無隣庵の地を手放し ${ }^{201}$ 、後述するよ うに、南禅寺近傍に新たな第三次無曜庵の造営を始める。したがっ て山縣がこの地を所有していたのは 1 年 4 か月間という短期間であ
り、かなり慌ただしく別邸が移転されたことが筫える。

山懸のこの別邸移転については、周辺に商工学地としての䀼いか 及んできていたことで当地が無䑝尾の号に適う地でなくなっていた ことが理由としてあげられる21)。しかし先の新聞記事で山縣は第 二次無嚾黾の敖地の拡張を計画しており、ここではなお当地で継続 して別邸を営むことを前提としていたものと考えられよう。した がって 4 か月後の第二次無隣庵の売却は、山縣自らか周辺の賑いを

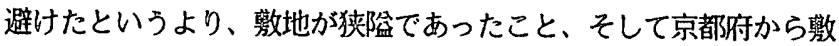
地の拡張が楒められなかったことに直接の原因があったと考えられ る。結累として京都府からの何らかの指示に従ったと解することも 可能であろう。

ところで別邸の拡張を計画していた明治25年 (1892)、山縣は 6 月17日より 2 週間程度、第二次無嚾庵に滞社した。「日出新聞」は 滞在中の山县系の様子を伝えている。（】】内は揭载日）

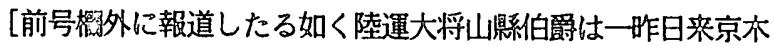
屋町二條下る別荘に投し昨日は降雨の為何れへも出でず同日朝 尾越翌記官訲問し一時間計り對話し続て飯倉少佐来訪したり伯 は来客に接する餘暇には久原正 ${ }^{(7 ?)}$ 三郎と園碁し或は押(?マ) 毫 を試み居れり]

『明治25年 6 月19日】

[ (山縣) 伯は来京以来不屋町の別荘に於て久原庄三郎氏を相 手に揮豪又は圍基を試み䦥日月を送り居れり一昨日は中井婪洲 山人と寒を園み午後より相携へて南禅寺近傍を散策したる由又 昨日は北垣知事午前より訪問して一時間餘談話し居りし由京都 には二週間許り滞在する筈にて本月下旬か来月上旬頃斯里山口 へ向け出発する都合なり]

『明治25年 6 月21日】

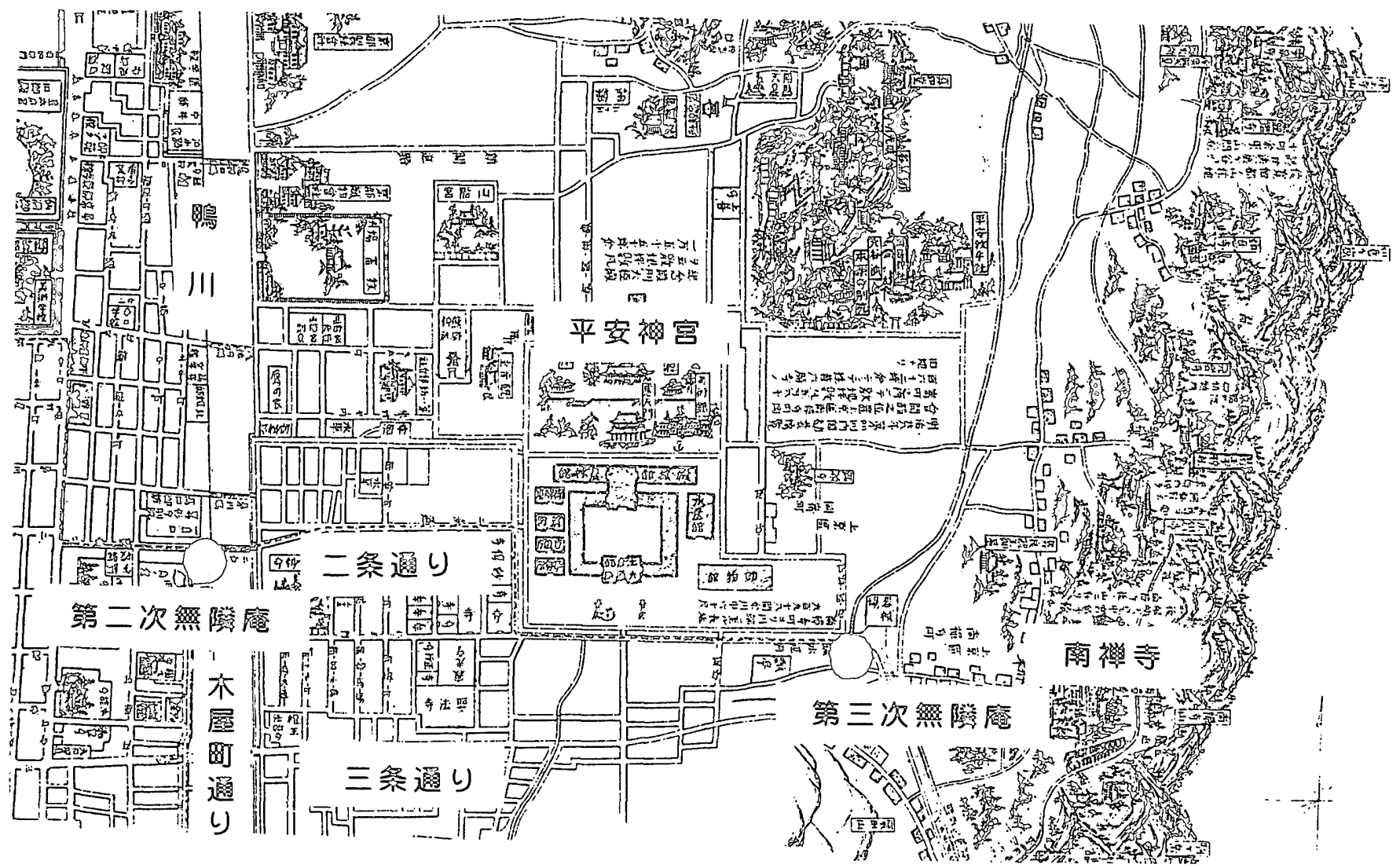

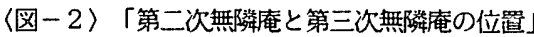

田中治兵衛編著『新撰 京都古今全図』1895 をもとに作成。 
[目今木屋町の別荘に滞在中なる山縣伯は両三日来降雨の為め 終日閑居し中井櫻洲山人并北垣府知事の外絶へて客に接せず時 に久原庄三郎氏と圍基を試み居ると云ふ]

\section{【明治25年 6月23日】}

上の 3 つの記事を見る限りでは山眯は、第二次無隣庵を売却する 直前の別邸滞在中に、京都府行政や実業界の有力者らと接し、とも に南禅寺近傍を散策するなど閑日月を過ごしていた。

山縣滞在中に第二次無隣庵を訪問し、山縣と親しく接していた久 原庄三郎（1840～1908）は、実弟の藤田伝三郎と藤田組を創立しそ の土木部門を管掌、日本土木会社などの諸企業に参画するなど、主 として阪神地方で活躍した実業家である。庄三郎の四男・房之助は 久原財閥を形成、聥信相や立憲政友会の総裁としても知られ $3^{22)}$ 。また中井櫻洲山人とは中井弘（1838～1894）のこと。濼賀 県知事時代の明治17年 (1884) 、北垣国道京都府知事らとともに琵 琶湖疏水工事を認可および着工させた人物で、京都岡崎の地に内国 勧業博覧会を誘致したのも中井であった。明治26年 (1893) 11月か ら翌27年（1894）10月までは第 5 代京都府知事（京都市長兼任）を 務めている23)。

売却直前の第二次無隣庵で、山縣と久原や中井との間で何か話し 合われていたのか知る術もない。しかし、山縣の有力者との動向が 報道され、その後に山縣が第二次無隣庵を売却し東山南禅寺の近傍 に第三次無隣庵を造営する事実を勘案すると、山縣の第二次無隣庵 売却と南禅寺近傍での第三次無隣庵の建設に、久原や中井が何らか の関わりをもっていたとする仮定も成立しよう。琵琶湖疏水完成以 後、東山の風致保存を前提とした新たな発展を期待する京都府行政 や実業界の有力者が山縣に新たな別邸造営を促し、敷地として疏水 の水が容易に利用できる南禅寺畔近傍の地を提示していたとした ら、山縣の第三次無隣庵への慌ただしい別邸移転も理解されるので ある。特に琵琶湖疏水を開通させ、それに伴う東山地域の新たな発 展を促す立場にある中井にとっては、南禅寺近傍で山縣に疏水の水 流を利用した別邸造営を積極的に促す理由があったものと想像でき る。

\section{2 第三次無隣庵の造営}

南禅寺近傍で第三次無隣庵の造営がいつはじまったのか、必ずし も明確でない。例えば『京華林泉帖』（註18参照）所収「無隣奄林 泉」の解説では「南禅寺總門内の北に在り明治二十五年山㲘公爵の 別邸として開設せられし所なり」として、別邸の開設時期を山縣か 第二次無隣庵を売却したのと同じ明治25年 (1892) にしている。こ れは、第二次無隣庵の売却と同時にすでに南禅寺畔での第三次無隣 庵造営の準備が始まっていた可能性を窥わせるものである。

明治33年（1900）11月、黒田天外が第三次無隣庵を取材した時の 記録 $^{24)}$ に、山縣の言葉として「此庭園は此前の川から此方へは、 明治二十七年に久原に托して作らしておいたので、其後二十八年の 丁度此䪸に、清国から帰って少し闑暇であったから、川の彼方の地 面を借入れて新たに作ることになった」とある。ここで「久原」と は明治25年（1892）、山縣滞在中の第二次無隣㭺を訪九、山眯と親 しく接していた久原庄三郎であろう。明治27年 (1894) 清国に出征 中の山涀系はこの久原に託して南禅寺近傍で第三次無隣庵の造営を始 めていた。第三次無隣庵の造営の初期の段階で久原庄三郎か築庭に 関わっていたことは、第二次無隣庵から第三次無隣庵への慌ただし
い移転に久原が関わりをもっていたとする先の仮定を裏づけるもの として注目される。

そして翌28年（1895）からさらに庭園の拡張工事がはじめられ た。同年 4 月19日、山縣は滞在先の広島から東京の有力官僚である 田中光顕に書簡を送った。次はその一部である。

[扠南禅寺別墅八新築潚濯水声松籟二和シ貴意二適シたる報道 を得必らず我心二叶ひ可申と相楽申候 $\left.{ }^{25)}\right]$

久原に託して工事を起こしていた南禅寺別荘は、その立地条件な ど山縣の好みに適うものであったのだろう。拡張工事の完成を楽し みに待つ山縣の心情が窥い知れる。

同28年（1895） 8月 8日付の「日出新聞」には次の記事がみえ る。

[洛東は南禅寺町の山縣侯爵別荘へは今回水利事務所より鉄管 を敷設して庭園の鲯水其他使用水料に充つる為め引水工事に着 手したるがその水量半個にして工費は五百円内外の予算にて竹 内全所技手工事を担当し両三日中に落成するよし全別荘は昨年 来成功為し居るも侯爵は日清事件以来軍務に多忙なりしを以て 来京せさりしも今後は時々全別荘に滞在する都合にて器具其他 の準備も整ひ居る由]

拡張工事を継続しながらも、この頃には南禅寺の第三次無隣庵は 別邸としての一応の体裁か整い、建築も山縣の滞在に向けて準備が なされつつあったことが想像できる。以後「日出新聞」には山縣の 第三次無隣庵の滞在を伝える記事が散見される。

例えば明治28年10月19日には「山縣大将は一昨日午前四時三十五 分七攸着の汽車にて来京南禅寺なる別邸に投せり昨日午前には岩崎 弥之助、久原庄二郎氏訪問せし」と報じ、翌20日には「南禅寺に別 邸に滞在中なる山縣大将は一昨日午後本願寺法主大谷光尊師の訪問 を受けしが昨日は午前より新古美術展覧会を一覧せり」、同月26日 には「松方伯は昨日時代行列を見て後ち山縣大将を南禅寺の別荘に 訪ひ暫く対話」と見えるなど、この時山縣は南禅寺の第三次無隣庆 に滞在し、すでに別邸には政界や実業界の有力者たちが迎えられて いた。

次は明治29年（1896）12月22日付「日出新聞」の記事である。

[山䝮侯来京の期 山縣侯の南禅寺別荘の庭園工事も目下粗ぼ

落成を告げたるより一応検分を申出でたれば全侯爵より本年は 到底出京出来難きを以て一月二日東京を発し当地へ来る旨の返

書ありたりと云ふ]

庭園の拡張工事が明治29年12月までにひとまず完成をみたことが 伝えられている。そして翌30年 (1897) に山鲧の検分が行われたの だろう。

以上から、南禅寺の第三次無隣庆は久原庄二郎などの協力を得て 明治28年 (1895) 8 月頃には山縣有朋の別邸として一応の体裁が整 い、10月には山縣の滞在や賓客の訪問を迎えることか可能な状態に なっていた。その後も庭園の拡張工事は続けられ、翌29年 (1896) の12月には拡張工事の完成をみた。また、先の新聞記事から第三次 無隣庵には政界・実業界の有力者の訪問が頻繁であったことが明ら かになる。山縣の別邸は単に山縣自身の保養の場であるばかりでな く、政界や実業界の有力者との交流の場であり、言わば中央から離 れた政治の場でもあったといえよゔ'。

ところで、京都地方法務局所管登記簿で第三次無隣庵の土地所有 
者の变遷をみると、敷地の西部（南禅寺草川町31）が売却されて山 縣の所有となるのは明治29年 (1896) のことである。それまでの所 有者は京都市であった。また敷地の東部（南禅寺草川町30-6）が山 縣の所有となるのはさらに遅れて明治35年 (1902) のことである。 それまでここも京都市の所有であった27)。したがって、山縣は明 治29年まで京都市所有の敷地て庭園を築庭し、完成させていたこと になる。

次に明治30年（1897）8月 3 日付の「京都日出新聞」の記事を見 る。

[山縣候の奇附 山縣候は洛東南禅寺町字忡川に別荘を新築し 防火用水として疏水運河の水を引き昨今工事大に進渉したれば 将来京都市水利毫業の隆盛を企図する為め金二百圓を三十年度 水利重丵覺の内へ寄附したき旨昨日市参專会へ出願せり]

先に明治28年（1895）8月8日付「日出新聞」でみたように、第 三次無榉黾への鉄管の敷設と引水工事は竹内京都市水利事務所技手 の担当で行われていた。その工事での京都市水利事務所の協力に対 する这礼として、山縣は寄附を申し出たのであろう。寄附の事害に ついては不明だか、南禅寺近傍での第三次無隣庵の造営が京都市の 敷地で、京都市水利事務所の稫極的な協力のもとで行われ完成して いたことは明らかでる。

\section{3 まとの}

明治23年（1890）に琵琶湖疏水第一期工事が竣工する以前、水路 が通過する恵山地域では水車動力を得るに有利な地理的条件をもっ て、工場が建設されはじめていた。明治維新以来の復興を目指す京 都にとって、工場建設がもたらす地域の㯲栄に大きな期待が寄せら れていた。ところが、明治25年（1892）に電気事業が開始され、京 都市内広域に電力の供給が可能になったことで、琵琶湖疏水に水路 付近で工場建設を促す積極的な要因が失われた。その後明治33年 （1900）、内貴甚三郎初代京都市長は新しい京都構想を提案する。 人口增加の推進を旨とするその構想では京都市内の地域別開発棈想 が示されており、真方は風致保存の必要性が謳われた。

明治39年（1906）10月24日の「日出新聞」で、鴨川曺岸の吉田村 聖讙院で予定されていた工場建設が京都府知事より認可されなかっ たことが報じられた。そこでは当地域が将来別荘地として発達すべ き見込があり、工場建設は風致を害する恐れがあることが理由とさ れていた。先の内貴京都市長の曺方の風致保存構想と連動して付近 には別邸地が形成されつつあったことが窺え、事実この時期、南禅 寺を中心とする東山地域で別邸の建設、あるいは別邸建設に発展す る土地取引がなされていたことが確認できた。

南禅寺近傍を中心とする褁山地域で最初期に別邸を営んだと目さ れる山縣有朋は、明治24年（1891）の7月に木屋町二条の地を購入 し第二次無隣庵を営んだが、翌25年（1892）年11月、所有してから 1 年 4 か月後にそこを手放し、南禅寺近傍に新たに第三次無㱛庵を 造営する。この別邸移転は山縣がホ屋町二条の所有地の拡張計画を 京都府に出願したが拒否されたことに直接の原因があったと推察さ れた。また、明治25年の第二次無隣庵の売却と同時に第三次無隣应 の造営準備が始まっていた可能性もあり、山縣の慌ただしい別註移 転と南禅寺近傍での第三次無隣庵造営には、当時山縣と親しく交遊 をもっていた中井弘や久原庄太郎といった京都府行政・実業界の有

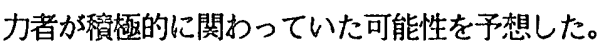

南禅寺近傍では最初、多忙の山縣に代わって久原が第三次無㔍庵 の造営を始めていた。明治28年（1895）8月頃には別邸としての一 応の体裁が留い、以後山縣は第三次無隣庵で多くの政界・害業界の 有力者たちの訪問を迎えた。同29年に初期の工事は完成するが、工 事が完成した明治29年 (1896) まで、第三次無缆庵の土地は京都市 の所有にかかるものであり、山縣は京都市から提供された土地で別 邸の築庭を行っていた。また、琵琶湖疏水から庭園への引水工事は 京都市水利事務所の㘔極的な協力のもとで行われていた。

以上から、琵琶湖疏水開通以降の東山地域では、当地域の風致保 存の動きと連動して別邸地が形成され始めており、最初期に造営さ

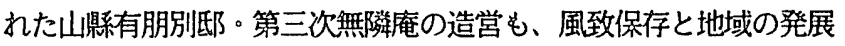
を進める立場にある京都府行政や害業界の有力者によって推進され たもので、京都市や水利事務所の穓極的な協力のもとで造営された ことがわかった。山縣の別邸の存在は、京都での政治の場の存在を も意昧するものでもあり、賁西の貴顕たちに別邸地として京都の曺 山地域を注目させる契機にもなったと想像される。山縣の別邸造営 に際しての、有力者や行政の協力もそれを見込んでのことであった のだろう。やがて専山地域で別邸地が形成されていくにいたるきっ かけは、当地域の風致保存を前提としたあらたな発展を促すために 人為的に導かれたものであったと考えられる。

【註】

1)これまで、当地域のこのような施設に関する論稿は少なくなく、遺構につい ても個別に調査が進められている。特に代表的なものでは、まず中村昌生博士 の一連の研究があげられる。博士は早くから南禅寺近傍の別比に注目され (博 士はこれらを多くの場合「山荘」とする)、調直結果を『和風建築』や『新住 宅』などの関連雑誌等で報告を続け、さらに『数寄屋邸宅集成 第三巻 京の 別業』などの大著としてまとめられた。鈴不博之博士は当地域で多くの庭園の 造営を手がけた庭師・㥀治こと小川治兵衛の活動に注目され、近代の和風空間 の性格を知る上で、その解明の重要さをいち早く指摘された（「明治から昭和 にいたる数寄屋一植治の世界」『建築雑誌』97巻1195号 pp10-13 建築学会 1982年など）。造園史の分野ではこれらの庭園に関する報告は多く、近年では 尼崎博正博士が精力的に調㿽研究を続け、琵琶湖疏水によってもたらされた水 系と東山の庭園文化圈の成立との関係を「南禅寺界隈疏水園池群の水系」

（『瓜生』第7号 pp61-77 京都芸術短期大学 1984）など一連の論文にまと められた。また、別邸群の成立や庭園の作庭に直接かかわった庭師・植治の活 動については、尼崎博士を代表とし、筆者も参加する「植治研究会」が研究成 果を『植治の庭一小川治兵衛の世界』（尼崎博正編 淡交社 1990）にまと め、その解明作業は今も継続中である。

2) 尼崎前揭「南禅寺界隈疏永園池群の水系」

3) 本節は、拙稿「明治期における南禅寺近傍の別荘地開発」（京都工芸瀻維大 学工芸学部学術報告『人文』第38巻 pp49-77 1990）の内容の一部を整理し発 展させたものである。

4)『京都の歷史・8 古都の近代』（学芸書林 1975）所収の『起工趣意書』 には、当初疏水事業の目的として、「一、水力、すなわち水車動力による製造 工業の近代化 三、運翰の利便 三、洛北地域の灌澌 四、精米の水力 による動力化 五、市街地の防火用水および飲料水の確保 六、放流によ る市内小河川の浄化」の6 項目が挙げられている。 
5)『琵琶湖疏水及水力使用事業』（京都市電気局 1940）所収。同市街画定案 は明治22年、北垣京都府知事によって決済されている。な拉、編入地域とは、 明治21年（1888）6月、京都市に編入された地域で、鴨川以東の粟田口・南禅 寺・吉田・岡崎・浄土寺・鹿っ谷および今熊野・清闌寺の各地域を示す。本稿 で対象とする東山南禅寺近傍地域は、この時京都市に編入された。

6) 京都織物株式会社に関する記述は、『京都織物株式会社全史』京都織物株式 会社全史刊行会 1969）による。

7)桜井景雄著『南禅寺史』（1940 法蔵館）

8) 前揭『疏水及び編入地域（二十一年）を中心とする市街画定案』では「新市 街中新設スへキ路線ノ位置並道路等級及七道路幅広狭取調説明書」として、明 治21年に新たに京都市に編入された鴨東地区を 9 つの地域に分け、発展の見込 みの程度を等級付けしている。南禅寺近傍に関わる地域については以下のよう に説明されていた。

第二（前略）「インクライン」下ヨリ鴨川迄疏水本線両側道路（疏水事務 所ヨリ工事施工八分）及若王寺前ヨリ西疏水本川北側道路二合スル処迄八 工商業共運河ノ利用ヨナス尤適当ノ場所、随テ往来頻繁ノ見込二付一等卜 ナス

第三（前略）鴨川牧埸南角ヨリ聖護院町黑谷門前迄及七粟田青蓮院門前ヨ リ吉田町习経テ高等中学校前迄、又二条通藤井紡績会社東側仏光寺ヨリ聖 護院习横断シ百万遍際道路迄、此三線路八商工業共二営業ヨナス新市街中 最良ノ場所ニシテ（後略）

第四 南禅寺山門ヨり永観堂前若王寺前 経テ銀閣寺門前迄、此道路二沿つ 処ノ土地八商工業ノ利用上二於テ八他ノ道路二比シ稍ヤ劣ル処アル卜雖卜

モ、大差ナキノミナラズ就中新市街ノ漸つ熱䦨地卜ナル二随七、工ノ為メ 商ノ為入其ノ他社交上ノ為入内外人久入京スルモノ日一日二增加スル火习 見儿如シ (後略)

以上から琵琶湖疏水の開通が当地域の商業あるいは工業地域としての発展を 促し、南禅寺門前から永観堂、銀閣寺門前にいたる地域は商工業の発展に加え て、「社交」を目的とした眼いを予感させていたことがわかる。

9）『京都大事典』（淡交社 1984）、前掲『京都の歴史・8 古都の近代』な ど。

10）前揭『京都の歴史・8 古都の近代』を参照。原典は『京都市会議事録』 (明治33年)

II）京都において、周䢞山林の管理による風致保存の動きは明治の初期から見 られるという(中島節子「明治初期から中期にかけての京都の森林管理と景観 保全」日本建築学会計画系論文集 第 481号 pp213-222 1996年3月 ほか)。 また、明治28年9月25日付「日出新聞」は、京都府が京都の名勝地の風致保存 の方法について、山林の保護を中心として調査を進めていることを報じてい る。対象となった地域は東山のほか宇治・嵐山・高雄・相尾の各地域で、何れ も官有山林であるが、地方庁の責任において皘極的な風致保存の方策が新たに 検討されていた。

12）前揭『京都の歷史・8 古都の近代』

13）拙稿「對龍山荘の建築」（前揭『植治の庭一小川治兵衛の世界』pp71-74）

14）前掲『京都織物株式会社全史』

15）土地の所有者の変遷は法務局所蔵の登記資料による。角星合資会社（およ び経営者・塚本與三次）による別荘地開発の実態については未た不明な点が多 いが、石田潤一郎・中川理・橋爪慎也「明治期以降の京都市およびその周辺地 域における住宅地形成事業について一近代日本の市街地形成に関する考察（そ の1）」（昭和63年度日本建築学会近畿支部研究報告集 pp909-912 1988）に 触れられており、また拙稿「近代京都の東山における別荘地の形成と数奇空

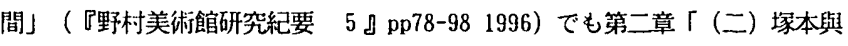
三次と角星合資会社の土地開発」として概要を報告している。

16）高橋箔庵著「目白椿山荘講評」（『篣のあと 上』秋豊園 1933 所 収）、あるいは『山県公遺稿・こしのやまかぜ』（東京大学出版会 1979 復 刻) 所収の解題ほか、山縣の趣味的生活に関する論評は大方一致していると思 われる。
17）山縣が生涯に営んた邸宅の变遷は、鈴木博之著『山縣有朋邸 小田原古稀 庵調查報告書』（千代田火災海上保険株式会社 1982）に詳しい。

18）京都地方法務局所管登記簿による。また明治 42 年、京都で全国園芸大会が 開催されるに際して発行された名園案内書とでもいうべき湯本文彦著『京華林 泉帖』（京都府庁 1909）の「田中氏二條樋口邸林泉」に「舊角倉氏別邸にて 本邸と高瀨川を隔てて其東に在り直に鴨川に臨み高瀨川の全水其邸内を過く明 治の初め上地の後山影公爵及ひ川田男爵小一郎清水吉次郎を経て近年大阪田中 市兵衛の所有たり」とある。

19）拙稿「山縣有朋の庭園観についての一考察」(京都工芸稢維大学工芸学部 研究報告『人文』第39巻 pp. 49-61 1991)

20）京都地方法務局所管登記簿によると、木屋町二条の同地は明治 25 年11月、 山縣有朋から三野村利助へ売却された後、26年 3 月に川田小一郎、36年 8 月に 清水吉次郎、39年12月に田中市太郎、大正 7 年12月には阿部市太郎にと、その 所有権が移転する。註18）の通り『京華林泉帖』には「田中氏二條樋口邸林 泉」としてこの庭園が紹介されており、水量豊かな川が樹間を流れる様子が写 真で揭載されいている。しかしこれは川田小一郎の時代に改修された可能性か あり（『同書』解説）、山縣時代の姿がどの程度伝わっているのか不明であ る。また大正 9 年、阿部市太郎の時代に庭師・植治 (小川治兵衛) によってさ らに改修されている（山根德太郎編『小川治兵衛』1965 所収「小川治兵衛年 譜」)。昭和32年以降も新たな所有者によって乎が加えられ、現在に至ってい る(尼崎博正「明治期に築造された京都の庭園一『京華林泉帖』の庭園観との 係り」京都芸術短期大学研究紀要『瓜生』第11号 ppl-10 1988年)。

21）例えば、湯本前掲『京華林泉㕷』所収の「無隣庵林泉」では「明治辛卯 （24年…筆者註）二條樋口角倉舊別邸を得其號を移さる （中略） 未た幾年 ならす其煩嚣を避け新に此邸（第三次無隣庵…筆者註）を營み仍蓃號を移し無 隣庵號し（下線筆者）」と説明している。

22）新潮社辞典編集部編『新潮日本人名辞典』（新潮社 1991）

23）前揭『京都大事典』および前揭『京都の歴史 8 占都の近代』による。 なお、京都市はこの当時特別市政をとっており、京都府知事が京都市長を兼任 していた。

24）黑田天外著『続江湖快心録』（1907）。これは美術評論家・黒田天外の名 邸訪問記で、はじめ「日出新聞」に連載された記事が後に『江湖快心録』 （1901）、『続江湖快心録』（1907）、『続々江湖快心録』（1913）の三編に 編集されている。

25）『山縣有朋文書 書翰其八他（6）』(国立国会図書館酙政資料室蔵) 26）例えば、明治36年（1903）4月21日、日露開戦への方針を決定したとされ る、いわゆる「無隣庆会議」がここで行われたことは周知の通りである。 27) 尼崎前揭「南禅寺疏水園池群の水系」。この事実に早くに気付かれた尼崎 博士は「無隣淹の数地は、明治25年（1892）の時点で京都市の所有であり、地 目はすでに宅地であった。その大部分が山県有朋の所有となるのは、明治29年 のことである。したがって、小川治兵衛による作庭はそれ以後とみなければな らない。敷地の東端部は 6 年後の明治 35 年に有朋か所有した。この部分は、明 治33〜34年䪸まで京電の留置線があったところといわれる。したがって、滝流 打附近は、明治 35 年以後でないと作庭できなかった。」として第三次無隣庵の 作庭がいつかの時期に分かれていたことを示された。

（1997年 9 月 30 日原稿受理，1997年12月 2 日採用決定) 